\title{
Caffeine Intake during Pregnancy: What Are the Real
}

\section{Evidences?}

\author{
Thaís de Mérici Domingues e Paula ${ }^{1}$, Felipe Lioe Teh Shang ${ }^{2}$, Hélio Chiarini-Garcia ${ }^{1}$ and Fernanda Radicchi \\ Campos Lobato de Almeida ${ }^{1}$ \\ 1. Laboratory of Structural Biology and Reproduction, Federal University of Minas Gerais, MG 31.270-901, Brazil \\ 2. School of Physical Education, Federal University of Minas Gerais, MG 31.270-901, Brazil
}

\begin{abstract}
Caffeine is a substance presented in foods such as coffee, tea, soft drinks, chocolates and medicines and is commonly consumed by pregnant women. Due to its ability to cross the placental membrane and accumulate in the fetus body, caffeine and its metabolites have been contraindicated or recommended in small doses during pregnancy. Studies in rodents relate caffeine intake to lower rates of fertilization, embryonic implantation, changes in placental structure, increased occurrence of low fetal and placental weights, abortion and stillbirth. However, in humans, studies involving caffeine consumption are inconclusive. Methodological complexity, difficulty for measuring caffeine intake and ethical reasons are limiting factors for a more accurate conclusion. So far, caffeine recommendation ranges from 100 to $300 \mathrm{mg} /$ day. Even though researches have recommended low caffeine consumption by pregnant women in order to avoid deleterious consequences during gestation, a safe dose has not been established until now. The aim of the present review is to describe the main findings on the effects of caffeine consumption during pregnancy in both human and rodent experimental models.
\end{abstract}

Key words: Caffeine intake, pregnancy, caffeine recommendation, placenta.

\section{Introduction}

Caffeine is a stimulant from the xanthine group, consumed worldwide from coffee intake, and also from some varieties of tea, soda, chocolate, energy drinks and some medication. It is estimated that $89 \%$ of women aged 18-24 consume caffeinated beverages with an average intake of $166 \mathrm{mg}$ of caffeine per day [1]. In order to combat drowsiness, increase concentration or simply as a pre-pregnancy habit, its consumption is common during pregnancy, especially in the second trimester [2-4]. Due to the physiological degradation of caffeine in the body $[4,5]$, there are different recommendation doses depending on pregnancy status. In this sense, in non-pregnant population, the maximum daily intake recommendation for caffeine is about $400 \mathrm{mg}$, while in pregnant women, this daily intake recommendation

Corresponding author: Fernanda Radicchi Campos Lobato de Almeida, Ph.D, research fields: reproductive biology in vertebrates, nutrition reproduction interactions. ranges from 100 to $300 \mathrm{mg}$.

Epidemiological studies showed that pregnant women have a reduced consumption of this substance, although the consumption may vary from 120 to 300 mg per day, which is not guaranteed as a safe dose. One study estimated that the average daily consumption of coffee in pregnant women in US and Europe varies from 1.5 to 4.6 cups [6]. There is also a great difficulty in quantifying the ingested caffeine content, since its content can vary according to the type and management of the coffee bean, different types of foods preparation and food species [7, 8]. Also, caffeine degradation changes in accordance to individual metabolic characteristics, genetic factors and by the concomitant use of other substances such as tobacco and alcohol [7]. For example: a $150 \mathrm{~mL}$ cup of coffee may contain, on average, 100 to $150 \mathrm{mg}$ of caffeine varying according to the species of grain, the type of roasting and the beverage preparation method. On the other hand, a $150 \mathrm{~mL}$ of instant coffee 
contains about $27 \mathrm{mg}$ of caffeine, while the same amount of boiled coffee may contain up to $111 \mathrm{mg}$ $[6,9,10]$. In other sources, the caffeine content is also variable. In tea, for instance, an average content of $32-42 \mathrm{mg} / 150 \mathrm{~mL}$ is observed, whereas in cola drink and cocoa, an average content of 32-70 mg/330 mL and $4 \mathrm{mg} / 150 \mathrm{~mL}$ are observed, respectively $[6,8,11]$.

In humans, studies involving caffeine consumption and its association with adverse outcome on fetal development and/or birth show conflicting results because of the difficulty to access biological material and to measure the real caffeine content in the food eaten $[4,11,12]$. So far, the main sources of information on maternal caffeine consumption are epidemiological data and longitudinal studies from personal reports and food anamnesis of prenatal care. A recent published meta-analysis by the Cochraine Library [13] systematically assessed all the published studies on pregnant women, caffeine consumption and adverse outcomes. After exclusion of most of the published studies due to methodological inconsistencies, it was concluded that there is insufficient evidence in the human model regarding the consumption of caffeine and pregnancy outcomes, since good quality RCTs (randomized controlled trials) are lacking. Moreover, for ethical reasons, these studies are not recommended. Up to now, rodents are a well-suited model, since their placental tissue and caffeine metabolism are similar to humans $[2,10,14,15]$.

Therefore, the present review describes the main findings on the effects of caffeine consumption during pregnancy in both human and rodent models. Additionally the metabolic similarities and differences between both models are also described.

\section{Caffeine Metabolism}

Caffeine is an alkaloid from the trimethylxanthine group. In humans, its half-life may vary from 2 to 4.5 hours, reaching up to 12 hours. Once ingested, it is metabolized by a family of hepatic enzymes named cytochrome P450-oxygenases (CYP1A2) [3, 10]. Paraxanthine, theobromine and theophylline are the main products generated by enzymatic removal of the methyl groups.

The primary metabolite is paraxanthine, and it represents approximately $72 \%$ to $85 \%$ of the final caffeine metabolism [4, 7, 16]. Paraxanthine is considered an adenosine antagonist, since it has the ability to bind to adenosine A1 receptors in the CNS (central nervous system) and in the PNS (peripheral nervous system). Adenosine, via cellular signaling, controls excitatory stimuli, promotes reduction in motor activity and heart rate, increases sleeping hours and decreases neurotransmitters and hormones release. Once prevented from binding to its receptors through paraxanthine's antagonistic action, adenosine has its metabolic effects reduced while increases the number of circulation neurotransmitters $[4,17]$. That is the reason why caffeine is usually consumed as a stimulant: to increase vigilance, and reduce sleeping time and fatigue [7].

Theobromine, in turn, has pharmacological effects that include increased diuresis, stimulation of the cardiovascular system, smooth muscle relaxation and increased glandular secretion. However, it corresponds only to $10 \%$ of the caffeine degradation products [10]. In addition, theophylline corresponds to up to $5 \%$ of caffeine degradation and presents a chemical structure and a mechanism of action similar to those of caffeine, but with a longer half-life (3 to 9 hours or more) [4].

Both caffeine and all metabolites (paraxantine, theobromine and theophylline) are very small and highly lipophilic molecules. They all have the ability to diffuse through biological tissues by passive diffusion, crossing tissues with high selective permeability, such as the blood and hematotesticular barrier and the placental membrane [18, 19].

During pregnancy, due to increased circulation of estrogen, there is a reduction in the clearance and 
excretion of caffeine, theophylline and paraxanthine, leading to a high deposition in maternal and fetal tissues [13, 20,21]. With the gradual reduction of the P450-oxigenases cytochrome enzymes action, the half-life of those metabolites may increase proportionally with the gestation period, reaching up to 18 hours in the last trimester [22]. These substances freely cross the placental membrane and, once in the placenta, the fetuses and, later on the newborns, are unable to metabolize them, as their elimination is totally dependent on the renal system, which is not fully developed at that stage [23]. Tsutsumi and colleagues [22] reported a progressive reduction of the CYP1A1 activity throughout gestation in the first, second and third trimesters. In this study, all participants maintained the same amount of habitual caffeine ingestion before and during pregnancy. Hence, even a low caffeine intake daily could generate deleterious consequences during pregnancy, due to the reduction of its degradation-which will lead to its accumulation and subsequent transition across the placenta-associated with the fetus inability to efficiently eliminate it.

\section{Human and Rodents: A Comparison between Experimental Models}

Methodological biases risks are classically found in studies relating human consumption of caffeine during pregnancy. Observational cohort study designs failed to show any association between caffeine intake and poor pregnancy outcomes [12, 13]. Moreover, randomized controlled trials may prove to be difficult or even unethical. On the other hand, animal studies have shown to be more accessible and controlled, although some particularities need to be considered [24].

Placenta is the main exchange interface between mother and fetus during pregnancy. It is responsible for nutrient, gases and energy substrates transportation that enable the proper development of eutherian mammals [15]. Considering that the placenta aims to nourish and control the passage of various substances to the fetus, animal studies directed to clinical application require a placental model compatible with human characteristics [25]. Currently, rodents and nonhuman primates' models seem to represent the best models associating caffeine intake with pregnancy and fetal outcomes [19].

Both humans and rodents have the placenta identified as a discoid type due to its discoid shape. The maternal-fetal interaction is restricted to this common circular area named cotyledon [14]. Rodents have a single cotyledon, whereas humans have a group of cotyledons, which will form a discoid structure. From the perspective of maternal-fetal interaction, the placentae of primates and rodents are characterized by fetal vessels directly bordering the mother's blood (hemochorial placentation) $[14,26]$. However, comparing the number of placental layers forming a kind of barrier between maternal and fetal blood, rodents placentae are thichorial, with three-thophoblast cell layers, while humans placentae have only two layers [15]. These three-thophoblast cell layers give rodents greater resistance to substances such as caffeine. Such resistance results in a conversion factor that extrapolates human consumption doses in mouse and rat caffeine studies models [19, 27, 28].

The degradation of caffeine and its metabolites formation also vary according to the species studied. However, early investigations comparing pharmacokinetics of caffeine in humans and many animals demonstrated some similarities [19]. For example, caffeine absorption from the gastrintestinal tract reaches $99 \%$ in humans and animals approximately $45 \mathrm{~min}$ after its ingestion [29]. In both humans and rodents, caffeine is demethylated to three dimethylxanthines. Although nonhuman primates may initially be an appropriate model providing valuable data for extrapolation to humans, its main metabolite is theophylline. Consequently, it does not provide a good model for assessing the effects of caffeine on 
reproduction because paraxanthine is the predominant metabolite in the degradation in humans and its function is different from that of theophylline [19]. So far, rodents are considered a good model for human studies based on similarities of caffeine biodegradation (paraxanthine as the main caffeine degradation metabolite) and similar placental structure for pregnancy outcome comparisons [12].

\section{Caffeine and Pregnancy}

Caffeine is a molecule capable to cross the placental membranes, reaching the fetus circulation [2]. As the fetus is unable to metabolize it properly, it is exposed to the same level of caffeine ingested by the mother $[8,18,30]$.

The confirmation of the free passage of caffeine through the placenta, associated with the first studies with high doses of this substance in animals in the 60's and 70's [31-34], led the US FDA (Food and Drug Administration) to implement about 20 years later a recommendation either restricting or removing coffee consumption by pregnant women [35, 36]. Subsequently, the same institution issued a letter advising that the maximum intake of caffeine by pregnant women should be $200 \mathrm{mg} /$ day or 1.5 to 2 small cups of coffee [36]. Thereafter, it was also suggested that caffeine intake should be restricted up to $300 \mathrm{mg} /$ day after quantification studies in a large food sample and after clinical trials with humans and animals performed [3]. Currently, some research groups suggested that the maximum intake should be $100 \mathrm{mg}$ /day or less [9, 37, 38]. However, a consensus among the maximum caffeine intake has not been established up to now.

Some studies estimate that the daily consumption of coffee for pregnant women in the US and Europe ranges between 1.5 to 4.6 cups [1, 6, 27], and the prevalence of caffeine intake during pregnancy have been estimated to range between $69 \%$ to $79 \%$ [39]. It is known that coffee consumption sums with other commonly consumed caffeine sources, further enhancing its ingestion. This increase affects their proper quantification, making it difficult to establish a safe control of their ingestion [13].

Caffeine intake is negatively associated with gestational changes in animals, such as lower rates of fertilization and embryonic implantation, low birth and placental weight, greater number of stillbirths, increased expression of apoptotic markers and altered placental and bone formation [9, 27, 40-46] (Table 1).

Huang and colleagues [27] reported reproductive alterations in female mice treated with caffeine. All treated animals reduced the total conception rate, decreased maternal body weight gain during pregnancy. Yadegari and colleagues [20], using intraperitoneal doses of $150 \mathrm{mg} / \mathrm{kg} /$ day of caffeine in female albino rats during 1 to 5 GD (gestational days), reported that the treated group showed a significant decrease in implantation sites and the number of live newborn, suggesting that caffeine is likely to cause anti-fertility effects.

Momoi and colleagues [9] reported that modest daily maternal caffeine exposure altered regional embryonic arterial blood flow development and induced IUGR (intrauterine growth restriction). Huang and colleagues [27] reported similar results with rats and mice treated during pregnancy: IUGR, decreased placental and fetal weights and decreased fetal and tail lengths. The reduction in placental leptin expression, resulting in fetal restriction of intrauterine growth was also reported after increasing doses of caffeine in rat's prenatal periods. Recently, our research group evaluated biometric outcomes of caffeine in mouse placentae and fetuses at various gestational days (mid and late pregnancy). The animals received low (60 mg /kg/day), moderate (120 mg/kg/day) and high (240 mg $/ \mathrm{kg} /$ day) doses of caffeine before and during gestation. The treated animals showed longer estrous cycle length and lower pregnancy rates. Placental and fetal weights were lower in moderate and high dose groups only in late pregnancy (17.5 GD). These results suggest 
Table 1 Summary of several studies relating caffeine consumption and pregnancy outcomes.

\begin{tabular}{|c|c|c|c|}
\hline Publication & $\begin{array}{l}\text { Experimental } \\
\text { model }\end{array}$ & Intervention & Reported effect \\
\hline Gilbert \& Pisteyl, 1973 [32] & Rats & IP (intra-peritoneal) doses of caffeine (4 to $16 \mathrm{mg} /$ day). & $\begin{array}{l}\text { Even in low doses ( } 4 \mathrm{mg} / \text { day), caffeine suppresses the growth } \\
\text { of embryonic and fetal tissues. }\end{array}$ \\
\hline Terada et al., 1975 [33] & Mice & $\begin{array}{l}\text { Doses of } 150 \text { or } 250 \mathrm{mg} / \mathrm{kg} \text { of caffeine during } 8-19 \text { weeks } \\
\text { pre-pregnancy. }\end{array}$ & $\begin{array}{l}\text { Long-term ingestion of caffeine induced an increased fetal } \\
\text { death. } \\
\geq 200 \mathrm{mg} / \mathrm{kg} \text { of caffeine caused cleft palate, but did not reduce }\end{array}$ \\
\hline Elmazar et al., 1981 [42] & Mice & IP or oral doses of 100,200,300 mg/kg of caffeine at GD 14 & $\begin{array}{l}\text { utero-placental blood flow, placental transfer function or } \\
\text { amniotic fluid volume. }\end{array}$ \\
\hline Linn et al., 1982 [55] & Human & $\begin{array}{l}\text { Analysis of interview and medical-record data of } 12,205 \\
\text { pregnant women. }\end{array}$ & $\begin{array}{l}\text { No relation between low birth weight or short pregnancy length } \\
\text { and large coffee consumption after controlling smoking habit. }\end{array}$ \\
\hline Martin et al., 1987 [61] & Human & Prospective study of 3,891 antenatal patients. & $\begin{array}{l}\text { Maternal caffeine intake seems to exert an effect on birth } \\
\text { weight through growth retardation in newborns. }\end{array}$ \\
\hline Peacock et al., 1991 [54] & Human & Prospective study with 1,309 pregnant women interviewed. & $\begin{array}{l}\text { Association of alcohol, smoking and high quantities of caffeine } \\
\text { could increase the risk of poor fetal growth. }\end{array}$ \\
\hline Klebanoff et al., 2002 [23] & Human & $\begin{array}{l}\text { Analysis of serum concentration of paraxanthine of } 2,515 \\
\text { women during the third trimester of pregnancy. }\end{array}$ & $\begin{array}{l}\text { Paraxanthine concentration, which reflects caffeine } \\
\text { consumption, was associated with a higher risk of reduced fetal } \\
\text { growth, particularly among women who smoked. }\end{array}$ \\
\hline Bech et al., 2005 [56] & Human & $\begin{array}{l}\text { Cohort study with comprehensive interview on coffee } \\
\text { consumption of } 88,482 \text { pregnant women. }\end{array}$ & $\begin{array}{l}\geq 8 \text { cups of coffee/day is associated with a higher risk of fetal } \\
\text { death, especially after } 20 \text { weeks of gestation. }\end{array}$ \\
\hline Bech et al., 2007 [57] & Human & $\begin{array}{l}\text { RCT with } 1.207 \text { pregnant women drinking at least three cups } \\
\text { of coffee a day were recruited before } 20 \text { weeks of gestation. } \\
\text { Caffeinated instant coffee or decaffeinated instant coffee } \\
\text { (control group). }\end{array}$ & $\begin{array}{l}\text { Moderate reduction in caffeine intake in the second half of } \\
\text { pregnancy has no effect on birth weight or length of gestation. }\end{array}$ \\
\hline Browne et al., 2007 [64] & Human & $\begin{array}{l}\text { Associate the information collected by telephone interview } \\
\text { with risks of cardiovascular malformation. }\end{array}$ & $\begin{array}{l}\text { No evidence of an appreciable teratogenic effect of caffeine } \\
\text { consumption by the mother and cardiovascular malformation in } \\
\text { the children. }\end{array}$ \\
\hline Weng et al., 2008 [66] & Human & $\begin{array}{l}\text { Prospective cohort study with pregnant women adjusted for } \\
\text { caffeine intake of } \leq 200 \mathrm{mg} / \text { day or } \geq 200 \mathrm{mg} / \text { day. }\end{array}$ & $\begin{array}{l}\geq 200 \mathrm{mg} / \text { day of caffeine intake during pregnancy increased the } \\
\text { risk of miscarriage, independent of pregnancy-related } \\
\text { symptoms. }\end{array}$ \\
\hline Huang et al., 2012 [27] & Mice and rats & $\begin{array}{l}\text { Caffeine ( } 60,120 \text { and } 240 \mathrm{mg} / \mathrm{kg} \text { per day) before and during } \\
\text { pregnancy (mice); or caffeine }(20,60 \text { and } 180 \mathrm{mg} / \mathrm{kg} \text { per day) } \\
\text { from GD } 11 \text { to GD } 20 \text { (rats). }\end{array}$ & $\begin{array}{l}\text { Caffeine, in a dose-dependent way, delayed conception, } \\
\text { decreased placental weight and fetal bodyweight, and induced } \\
\text { placental apoptosis p 53-dependent. }\end{array}$ \\
\hline Tomaszewski et al., 2012 [41] & Rats & $\begin{array}{l}\text { Oral doses of } 30 \mathrm{mg} / \text { day from GD } 8 \text { to GD } 21 \text { (caffeine or } \\
\text { water). }\end{array}$ & $\begin{array}{l}\text { Caffeine consumed in large doses during pregnancy disturbed } \\
\text { the development of the bone tissue and its mineralization. }\end{array}$ \\
\hline Grant et al., 2012 [68] & In vitro study & $\begin{array}{l}\text { Culture of primary first-trimester EVT and EVT-derived cell } \\
\text { line to examine whether caffeine had detrimental effect on } \\
\text { trophoblast biology. }\end{array}$ & $\begin{array}{l}\text { Caffeine inhibits EGF-stimulated trophoblast cell motility, a } \\
\text { crucial determinant of pregnancy success. }\end{array}$ \\
\hline
\end{tabular}


(Table 1 Continude)

\begin{tabular}{|c|c|c|c|}
\hline Publication & $\begin{array}{l}\text { Experimental } \\
\text { model }\end{array}$ & Intervention & Reported effect \\
\hline Silva et al., 2013 [43] & Mice & $\begin{array}{l}\text { Consumption of } 0.3 \mathrm{~g} \text { of caffeine } / \mathrm{L} \text { dissolved in water, } \\
\text { beginning at GD } 0.5 \text {. }\end{array}$ & $\begin{array}{l}\text { Caffeine exposure during pregnancy and lactation in rodents } \\
\text { may have adverse effects on the neural development of their } \\
\text { offspring. }\end{array}$ \\
\hline $\begin{array}{l}\text { Serapiao-Moraes et al., } 2013 \\
\text { [44] }\end{array}$ & Mice & $\begin{array}{l}\text { Daily subcutaneous injections of caffeine }(20 \mathrm{mg} / \mathrm{kg}) \text { or } \\
\text { saline (control). }\end{array}$ & $\begin{array}{l}\text { Adult offspring with adverse cardiac remodeling and persistent } \\
\text { activation of local renin-angiotensin system in the kidney and } \\
\text { heart. }\end{array}$ \\
\hline Greenwood et al., 2014 [48] & Human & $\begin{array}{l}\text { Meta-analysis of dose-response curves for associations } \\
\text { between caffeine intake outcomes: spontaneous abortion, } \\
\text { stillbirth, preterm delivery, low birth weight and SGA infants } \\
\text { (Cohort and case-control studies). }\end{array}$ & $\begin{array}{l}\text { There is insufficient evidence to support further reductions of } \\
\text { the maximum recommended dose of caffeine intake. }\end{array}$ \\
\hline Momoi et al., 2015 [9] & Mice & $\begin{array}{l}\text { Subcutaneous administration of caffeine }(10 \mathrm{mg} / \mathrm{kg}) \text { from GD } \\
9.5 \text { to GD } 18.5 \text {. }\end{array}$ & $\begin{array}{l}\text { Modest daily maternal caffeine exposure has a negative effect } \\
\text { on embryonic cardiovascular function and embryonic growth, } \\
\text { possibly mediated via adenosine A2A receptor blockade. }\end{array}$ \\
\hline Ma et al., 2015 [46] & Chick embryos & $\begin{array}{l}5,10 \text { or } 15 \mu \mathrm{mol} \text { of caffeine or avian saline (control group) } \\
\text { injected into the egg air chamber. }\end{array}$ & $\begin{array}{l}\text { Caffeine exposure inhibited angiogenesis by targeting } \\
\text { angiogenesis-related genes. }\end{array}$ \\
\hline Del Castillo et al., 2015 [58] & Human & $\begin{array}{l}\text { Transversal study with } 175 \text { patients. Collected data about } \\
\text { caffeine consumption during first half of gestation and } \\
\text { perinatal outcomes by personal interview, medical records } \\
\text { and telephone calls. }\end{array}$ & $\begin{array}{l}\text { No relation between caffeine intake and low birth weight and } \\
\text { small gestational age or prematurity. }\end{array}$ \\
\hline Partosch et al., 2015 [69] & $\begin{array}{l}\text { Physiologically } \\
\text { kinetic model }\end{array}$ & $\begin{array}{l}\text { Daily doses of } 200 \mathrm{mg} / \mathrm{kg} \text { of caffeine given to pregnant or } \\
\text { non-pregnant models (concentration-time profile). }\end{array}$ & $\begin{array}{l}\text { Safe daily doses of } 200 \mathrm{mg} \text { of caffeine in pregnant women } \\
\text { should be taken in serial doses. }\end{array}$ \\
\hline Li et al., 2015 [72] & Human & $\begin{array}{l}\text { Meta-analysis to evaluate the association between pregnancy } \\
\text { loss and caffeine/coffee consumption in case-control and } \\
\text { cohort studies. }\end{array}$ & $\begin{array}{l}\text { Caffeine and coffee consumption during pregnancy could be } \\
\text { associated with an increased risk of pregnancy loss, in a dose } \\
\text { response relationship. }\end{array}$ \\
\hline Rhee et al., 2015 [73] & Human & $\begin{array}{l}\text { Meta-analysis and linear-dose response of population studies } \\
\text { correlating caffeine consumption and LBW. }\end{array}$ & $\begin{array}{l}\text { Caffeine intake appears to be linearly related to a significant } \\
\text { increase in the risk of LBW. }\end{array}$ \\
\hline $\begin{array}{l}\text { Jahanfar \& Jaafar, 2009, 2013, } \\
2015[13,70,71]\end{array}$ & Human & $\begin{array}{l}\text { RCTs meta-analysis including quasi-RCTs investigating the } \\
\text { effect of caffeine and/or supplementary caffeine vs restricted } \\
\text { caffeine intake or placebo on pregnancy outcomes. }\end{array}$ & $\begin{array}{l}\text { Insufficient evidence to confirm or refute the caffeine } \\
\text { consumption during pregnancy. }\end{array}$ \\
\hline Yadegari et al., 2016 [20] & Rats & $\begin{array}{l}\text { Intraperitoneal doses of caffeine }(150 \mathrm{mg} / \mathrm{kg} / \text { day }) \text { or water } \\
\text { (control group) on days } 1-5 \text { of pregnancy. }\end{array}$ & $\begin{array}{l}\text { Caffeine administration decreased the number of implantation } \\
\text { sites and number of live births. }\end{array}$ \\
\hline Gaskins et al., 2016 [65] & Human & $\begin{array}{l}\text { Prospective cohort study with } 15,590 \text { pregnant women with } \\
\text { no history of SAB. A self-reported questionnaire evaluating } \\
\text { caffeine intake during pre-pregnancy was also applied. }\end{array}$ & $\begin{array}{l}\text { Pre-pregnancy consumption of } \geq 4 \text { servings/day of caffeine is } \\
\text { associated with increased risk of SAB. }\end{array}$ \\
\hline
\end{tabular}

EVT: extravillous trophoblasts; GD: gestational day; LBW: low birth weight; RCT: randomized controlled trials; SAB: spontaneous abortion; SGA: small for gestational age. 
that caffeine doses can negatively affect fetal and placental development in late pregnancy even in lower doses (data not published).

Elmazar and colleagues [42] induced caffeine consumption in albino female mice intraperitoneally and orally, and described increased circulating corticosterone and cleft palate in litters, although no detection of reduced utero-placental or placental-fetal blood flow were reported at 14 GD. Silva and colleagues [43], exposing female mice to oral doses of $0.3 \mathrm{~g} /$ liter of caffeine (diluted in water), suggested that caffeine exposure by mouse pups during gestation and lactation had deleterious effects on neuronal development, hyper excitable hippocampus, susceptibility to seizures and cognitive deficits that could remain even in adult life. Serapiao-Moraes and colleagues [44] using C57BL/6 pregnant mice, with daily subcutaneous caffeine doses of $20 \mathrm{mg} / \mathrm{kg}$, reported negative outcomes in adult offspring from treated mothers. Besides the lower weight gain during growth and impaired basal metabolic rate, the adult animals showed an increase in cardiomyocytes size and a lower vascularization of cardiac tissue.

During pregnancy, bone abnormalities are also described in fetuses from mothers treated with caffeine. Olchowik and colleagues [45] reported that $30 \mathrm{mg} /$ day of caffeine intake during pregnancy had negative influence in female rats' bone tissue. Tomaszewski and colleagues [41], using X-ray microprobe to examine female rats fetuses treated with $30 \mathrm{mg} /$ day of caffeine, observed that the decreased bone mineralization was dominant in the treated group.

Despite several studies involving growth, birth and development of the offspring, studies describing possible changes in placental histomorphology and physiology post-exposure to caffeine are scarce. Huang and colleagues, [27] by inducing a dose-dependent consumption of $180 \mathrm{mg} / \mathrm{kg}$ of caffeine during pregnancy in Wistar rats, observed edematous regions in the endoplasmic reticulum, expansion of the cisterns of the rough endoplasmic reticulum, ribosomes degranulation and heterochromatin condensation in thophoblast cells. It was also observed an increased apoptosis and inhibitions of angiogenesis following exposure to a "chicken functional placenta” by excessive of caffeine intake [46]. The term "chicken functional placenta" was adopted by the authors of that study from the observation of morphological similarity between the yolk sac and the choriallantoic membranes of a bird compared to the villi of a mammalian placenta. It is important to note that most studies of placental phenotyping and fetal mortality point out the poor development of placental labyrinth, especially caused by circulatory abnormalities [47].

Much has been already concluded upon the effect of caffeine in animals, although the mechanisms involved in these findings still remain unclear. More studies are needed to explain what the structural changes caused by caffeine during placental development, and whether these changes and mechanisms could also happen in humans.

As the information is obtained through epidemiological studies in humans, caffeine quantification is measured from serum and/or urinary biomarkers as an attempt to obtain a more accurate result. However, all these biomarkers are influenced by the metabolites half-life, the time in which the sampling was performed and other factors such as smoking, gestational age and exacerbated vomiting [4, 48-54]. One study attempted to establish an association between measures of caffeine from maternal urine, umbilical cord's blood, and maternal self-report [52]. This study concluded that serum and urine biomarkers do not reflect the real caffeine exposure over pregnancy. The authors also suggested that maternal self-report is the best way to estimate daily consumption of caffeine rich food. Therefore, the study of caffeine consumption during pregnancy in humans is subjected to several types of bias such as selection, performance, detection, reporting and 
others [13].

Although evident results found in rodents show deleterious effect of caffeine consumption during pregnancy, human studies involving caffeine intake are still inconclusive since 1970. Several studies found no relationship between caffeine consumption and fetal abnormalities. However, such a relationship was found in pregnant smokers and/or drinkers who consumed high doses of coffee [53-55]. In this regard, Bech and cols [56] conducted a cohort study to determine whether caffeine consumption during pregnancy would be associated with late fetal death. The results showed that the consumption of more than 8 cups/day of coffee increased fetal death, especially after 20 weeks of gestation. However, the same group in 2007 [57], conducted a randomized double-blind controlled trial study, comparing gestational length and birth weight from newborns of 1207 pregnant women who consumed caffeinated or decaffeinated instant coffee. They concluded that a moderate reduction in caffeine intake in the second half of pregnancy has no effect on gestational length or on the newborn's birth weight.

Del Castillo and colleagues [58], using a cross-sectional study with 1,175 women, investigated whether caffeine intake during the first half of pregnancy could increase the risk of adverse perinatal outcomes. Although they found some weight reduction in newborn from mothers who consumed high doses of caffeine, no relationships between caffeine intake, low birth weight (defined as birth weight less than $2500 \mathrm{~g}$ ) and low gestational age or prematurity were found.

In contrast, many other studies suggested the occurrence of harmful effects by excessive consumption of caffeine in women during pregnancy. Some authors showed higher frequency of delayed intrauterine fetal growth of mothers who consumed caffeine in the third trimester of gestation [59-65]. Spontaneous abortions and/or fetal malformations were also associated with the consumption of this substance, although the methodological complexity and the difficulty for measuring caffeine intake would limit a more accurate conclusion [59, 60, 64]. Gaskins et al. [65], through a prospective cohort study, identified a linear trend between the consumption of more than $400 \mathrm{mg}$ of caffeine/day (approximately 4 doses of coffee) before pregnancy and the occurrence of SAB (spontaneous abortion) before 20 weeks of pregnancy of women with no history of SAB. Compared with women who did not consume coffee during the pre-pregnancy period, the risk of SAB increased by $20 \%$. Other caffeinates beverages reported by patients were not associated with this risk. Similar results had previously been described by Weng and cols [66] who observed in their prospective cohort study that pregnant women who ingested more than $200 \mathrm{mg}$ of caffeine throughout pregnancy, increased the risk of miscarriage up to $25 \%$

In vitro and ex vivo perfusion models, like cultured human placental cells, have also been explored in an attempt to establish a safe dose of caffeine consumption during pregnancy [67-69]. In 2014, an ex vivo perfusion of the human placenta proved that caffeine freely crosses the placenta by passive diffusion, as previously reported, regardless the dose used [67]. Using an in vitro model, Grant et al. [68] observed that caffeine inhibits EGF-stimulated trophoblast invasion and motility, which could lead to pregnancy disorders such as early pregnancy loss and preeclampsia. Thus, according to these authors, the consumption of caffeine should be discouraged. Moreover, Partosch and cols [69], using a physiologically based kinetic model to predict a simulated caffeine blood concentration-time profile in non-pregnant and pregnant women, recommended that caffeine doses should be less than $200 \mathrm{mg} /$ day, divided into separate portions during the day.

Many meta-analyzes were performed associating caffeine intake and adverse outcomes during pregnancy. However, so far, only inconclusive results were found. In its periodic meta-analyzes updates of 
randomized controlled trials in humans, Jahanfar and Jaafar $[13,70,71]$ stated that there are insufficient evidences to support alterations in the maximum caffeine recommendation intake by mother on general pregnancy disorders. Greenwood and cols [48] concluded in their meta-analysis in a similar way as Jahanfar and Jaafar. On the other hand, other meta-analyzes of observational studies associated caffeine consumption with several negative outcomes during pregnancy. $\mathrm{Li}$ and cols [72] performed a systematic meta-analysis reviewing coffee and caffeine consumption with pregnancy loss, and found a dose-dependent association pointing to a potential risk of this gestational outcome. Rhee et al. [73] focused their meta-analysis on cohort and case control studies that related the dose-dependent consumption of caffeine during gestation and the risk of LBW (low birth weight) newborn. The results showed that for each increase of $100 \mathrm{mg}$ of caffeine consumed during pregnancy, the odds ratio for LBW increased by $3 \%$, being this linear rise according to the dose consumed. Despite different methods, outcomes, and associations found in human studies, and taking into account previous findings in rodent studies, all meta-analyzes are still in agreement with the maintenance of current recommendations as a precaution (200 $\mathrm{mg}$ or less) while a new safe dose cannot be established so far. Since there is insufficient evidence to establish caffeine's safe dose, the current indication of the US Food and Drug is still used in clinical practice and applied in most of the studies evaluating the safety of this amount of caffeine during pregnancy.

\section{Conclusions}

Many studies, using animal experimental models, link chronic consumption of caffeine as one of the causative agents of pregnancy problems. Even though the consequences are well described, the exact mechanisms of the effects of caffeine intake during pregnancy on rodents and humans still remain unclear, and safe doses have not been established yet.
Given the available data on the deleterious effects in rodents, we recommend that caffeine consumption should be avoided by pregnant women, or consumed at doses lower than the recommendation of 200 $\mathrm{mg} /$ day. Clearly, more research is necessary to address longer term consequences of caffeine consumption during pregnancy, as various measurements including fetal, maternal and placental morphological outcomes should be considered in future studies.

\section{References}

[1] Frary, C. D., Johnson, R. K., and Wang, M. Q. 2005. "Food Sources and Intakes of Caffeine in the Diets of Persons in the United States." J Am Diet Assoc 105: 110-3.

[2] Dews, P. B. 2011. Caffeine: Perspectives from Recent Research. Berlin: Springer Science \& Business Media.

[3] Butt, M. S., and Sultan, M. T. 2011. "Coffee and its Consumption: Benefits and Risks." Crit Rev Food SciNutr.

[4] Grosso, L. M., and Bracken, M. B. 2005. "Caffeine Metabolism, Genetics, and Perinatal Outcomes: A Review of Exposure Assessment Considerations during Pregnancy." Ann Epidemiol 15: 460-6.

[5] EFSA. 2015. "Scientific Opinion on the Safety of Caffeine. Panel on Dietetic Products, Nutrition and Allergies (NDA)." EFSA J 13 (5): 4102.

[6] Barone, J. J., and Roberts, H. R. 1996. "Caffeine Consumption." Food Chem Toxicol 34: 119-29.

[7] Burke, L., Desbrow, B., and Spriet, L. 2013. Caffeine for Sports Performance. United States of America: Human Kinects.

[8] Arnaud, M. J. 1987. "The Pharmacology of Caffeine." Prog Drug Res 31: 273-313.

[9] Momoi, N., Tinney, J. P., Liu, L. J., Elshershari, H., Hoffmann, P. J., et al. 2008. "Modest Maternal Caffeine Exposure Affects Developing Embryonic Cardiovascular Function and Growth." Am J Physiol Heart Circ Physiol 294: 2248-56.

[10] Arnaud, M. J. 1993. "Metabolism of Caffeine and Other Components of Coffee." In Caffeine, Coffee, and Health, edited by Garattini, S. New York: Raven Press, 43-95.

[11] Bowes, A. D. 1989. Caffeine, Bowes' and Church's Food Values of Portions Commonly Used. Philadelphia: Lippincott, 261.

[12] Bracken, M. B., Triche, E., Grosso, L., Hellenbrand, K., Belanger, K., and Leaderer, B. P. 2002. "Heterogeneity in Assessing Self-reports of Caffeine Exposure: Implications for Studies of Health Effects." Epidemiology 
13 (2): 165-71.

[13] Jahanfar, S., and Jaafar, S. H. 2015. "Effects of Restricted Caffeine Intake by Mother on Fetal, Neonatal and Pregnancy Outcomes." Cochrane Database of Systematic Reviews 6.

[14] Burton, G. J., Kaufmann, P., and Huppertz, B. 2006. "Anatomy and Genesis of the Placenta." In Knobil and Neill's Physiology of Reproduction. 3rd ed., edited by Neill, J. D., et al. New York: Elsevier, 189-243.

[15] Rossant, J., and Cross, J. C. 2001. "Placental Development: Lessons from Mouse Mutants.” Nature Reviews 2: 538-48.

[16] Klebanoff, M., Levine, R., DerSimonian, R., Clemens, J., and Wilkins, D. 1998. "Serum Caffeine and Paraxanthine as Markers for Reported Caffeine Intake in Pregnancy.” Annals of Epidemiology 8 (2): 107-11.

[17] Harland, B. 2000. “Caffeine and Nutrition.” Nutrition 16 (7): 522-6.

[18] Mose, T., Kjaerstad, M. B., Mathiesen, L., Nielsen, J. B., Edelfors, S., and Knudsen, L. E. 2008. "Placental Passage of Benzoic Acid, Caffeine, and Glyphosate in an ex Vivo Human Perfusion System.” J Toxicol Environ Health 71: 984-91.

[19] Christian, M. S., and Brent, R. L. 2001. "Teratogen Update: Evaluation of the Reproductive and Developmental Risks of Caffeine.” Teratology 64: 51-78.

[20] Yadegari, M., Khazaei, M., Anvari, M., and Eskandari, M. 2016. "Prenatal Caffeine Exposure Impairs Pregnancy in Rats.” Int J Fertil Steril 9 (4): 558-62.

[21] Sesardic, D., Pasanen, M., Pelkonen, O., and Boobis, A. R. 1990. "Differential Expression and Regulation of Members of the Cytochrome P4501A Gene Subfamily in Human Tissues.” Carcinogenesis 11: 1183-88.

[22] Tsutsumi, K., Kotegawa, T., Matsuki, S., Tanaka, Y., Ishii, Y., Kodama, Y., et al. 2001. "The Effect of Pregnancy on Cytochrome P4501a2, Xanthine Oxidase, and N-Acetyltransferase Activities in Humans.” Clin Pharmacol Ther 70: 121-5.

[23] Klebanoff, M., Levine, R. J., Clemens, J. D., and Wilkins, D. G. 2002. "Maternal Serum Caffeine Metabolites and Small-for-gestational Age Birth.” Am J Epidemiol 155 (1): 32-37.

[24] Croy, A., Yamada, A. T., DeMayo, F. J., and Adamson, S. L. 2014. The Guide to Investigation of Mouse Pregnancy. London: Elsevier, 808.

[25] Silva, J. F., and Serakides, R. 2016. "Intrauterine Trophoblast Migration: A Comparative View of Humans And Rodents." Cell Adhesion \& Migration.

[26] Reynolds, L. P., Borowicz, P. P., Cation, J. S., et al. 2010. "Uteroplacental Vascular Development and Placental Function: An Update.” Int J Dev Biol 54: 355-65.

[27] Huang, J., Zhou, S., Ping, J., Pan, X., Liang, G., Xu, D., et al. 2012. "Role of P53-dependent Placental Apoptosis in the Reproductive and Developmental Toxicities of Caffeine in Rodents.” Clin Exp Pharmacol Physiol 39: 357-63.

[28] Wang, Y. 1999. "Basic Knowledge of Functional Experiment.” In Medical Functional Experimental Tutoria, edited by Hu, H. Z. Beijing: Science Press.

[29] Nehlig, A. 1999. "Are We Dependent upon Coffee and Caffeine? A Review on Human and Animal Data." Neuroscience and Biobehavioral Reviews 23: 563-76.

[30] Leon, D., Albasanz, J. L., Ruiz, M. A., Fernandez, M., and Martin, M. 2002. "Adenosine A1 Receptor Down-regulation in Mothers and Fetal Brain after Caffeine and Theophylline Treatments to Pregnant Rats.” J Neurochem 82: 625-34.

[31] Fujii, T., Sasaki, H., and Nishimura, H. 1969. “Teratogenicity of Caffeine in Mice Related to Its Mode of Administration.” Jap J Pharmac.

[32] Gilbert, E. F., and Pistey, W. R. 1973. "Effect on the Offspring of Repeated Caffeine Administration to Pregnant Rats.” J Reprod Fertil 34 (3): 495-9.

[33] Terada, M., and Nishimura, H. 1975. "Mitigation of Caffeine-induced Teratogenicity in Mice by Prior Chronic Caffeine Ingestion.” Teratology 12: 79-82.

[34] Nishimura, H., and Nakai, K. 1960. "Congenital Malformations in The Offspring of Mice Treated with Caffeine.” Proc Soc Exp. Biol Med 104: 140-2.

[35] FDA (U.S. Food and Drug Administration). 1980. "Caffeine and Pregnancy." FDA Drug Bull 10: 19-20.

[36] FDA (U. S. Food and Drug Administration). 2002. "Center for Science and Public Interest Publisher of Nutrition Action Health.” Letter.

[37] Partosch, F., Mielkeb, H., Stahlmann, R., and Gundert-Remy, U. 2015. “Caffeine Intake in Pregnancy: Relationship between Internal Intake and Effect on Birth Weight.” Food and Chemical Toxicology 86: 291-7.

[38] Wadge, A. 2009. "Caffeine in Pregnancy." Food Standard Agency's Advice on Caffeine.

[39] D’Amicis, A., and Viani, R. 1993. "The Consumption of Coffee." In Caffeine, Coffee and Health, edited by Garattini, S. New York: Raven Press, 1-16.

[40] Ballesteros-Yanez, I., Castillo, C. A., Amo-Salas, M., Albasanz, J. L., and Martin, M. 2012. "Differential Effect of Caffeine Consumption on Diverse Brain Areas of Pregnant Rats.” J Caffeine Res 2 (2): 90-8.

[41] Tomaszewski, M., Olchowik, G., Tomaszewska, M., and Burdan, F. 2012. "Use of X-ray Microprobe to Diagnose Bone Tissue Demineralization after Caffeine Administration.” Folia Histochem Cytobiol, 436-43.

[42] Elmazar, M. M. A., McElhatton, R., and Sullivan, F. M. 1981. "Acute Studies to Investigate the Mechanism of Action of Caffeine as a Teratogen in Mice". Human 
Toxicology 1: 53-63.

[43] Silva, C. G., Metín, C., Fazeli, W., Machado, N., Darmopil, S., et al. 2013. "Adenosine Receptor Antagonists Including Caffeine Alter Fetal Brain Development in Mice.” Science Translational Medicine 5: 197.

[44] Serapiao-Moraes, D. F., Souza-Melo, V. S., Aguila, M. B., Mandarim-de-Lacerda, C. A., and Faria, T. S. 2013. "Maternal Caffeine Administration Leads to Adverse Effects on Adult Mice Offspring." Eur J Nutr 52: 1891-900.

[45] Olchowik, G., Chadaj-Polberg, E., Tomaszewski, M., Polberg, M., and Tomaszewska, M. 2011. “The Influence of Caffeine on the Biomechanical Properties of Bone Tissue during Pregnancy in a Population of Rats.” Folia Histochem Cytobiol 49: 504-11.

[46] Ma, Z. L., Wan, G., Lu, W., Cheng, X., Chuai, M., et al. 2015. "Investigating the Effect of Excess Caffeine Exposure on Placental Angiogenesis Using Chicken 'Functional' Placental Blood Vessel Network.” J. Appl. Toxicol.

[47] Bolon, B. 2014. "Pathology Analysis of the Placenta." In the Guide to Investigation of Mouse Pregnancy, edited by Croy, A., Yamada, A. T., DeMayo, F. J., Adamson, S. L. London: Elsevier, 175-88.

[48] Greenwood, D. C., Thatcher, N. J., Ye, J., Garrard, L., et al. 2014. "Caffeine Intake during Pregnancy and Adverse Birth Outcomes: A Systematic Review and Dose-response Meta-analysis.” Eur J Epidemiol 29: 725-34.

[49] Kalow, W., and Tang, B. K. 1991. "Caffeine as a Metabolic Probe: Exploration of the Enzyme-inducing Effect of Cigarette Smoking." Clin Pharmacol Ther 49: 44-48.

[50] Aldridge, A., Bailey, J., and Neims, A. H. 1981. "The Disposition of Caffeine during and after Pregnancy." Semin Perinatol 5: 310-4.

[51] Parsons, W., and Neims, A. 1978. "Effect of Smoking on Caffeine Clearance.” Clin Pharmacol Ther 24: 734-9.

[52] Grosso, L. M., Triche, E., Benowitz, N. L., and Bracken, M. B. 2008. "Prenatal Caffeine Assessment: Fetal and Maternal Biomarkers or Self-reported Intake?” Ann Epidemiol 18 (3): 172-8.

[53] Olsen, J. 1991. "Cigarette Smoking, Tea and Coffee Drinking and Subfecundity.” Am J Epidemiol 133: 734-9.

[54] Peacock, J., Bland, J., and Anderson, H. 1991. "Effects on Birth Weight of Alcohol and Caffeine Consumption in Smoking Women.” J Epidemiol Community Health 45: 159-63.

[55] Linn, S., Schoenbaum, S. C., Monson, R. R., Rosner, B., Stubblefield, P. G., and Ryan, K. J. 1982. "No Association between Coffee Consumption and Adverse
Outcomes of Pregnancy.” N Engl J Med 306: 141-5.

[56] Bech, B. H., Nohr, E. A., Vaeth, M., and Olsen, J. 2005. "Coffee and Fetal Death: A Cohort Study with Prospective Data.” Am J Epidemiol. 182 (10).

[57] Bech, B. H., Obel, C., Henriksen, T. B., and Olsen, J. 2007. "Effect of Reducing Caffeine Intake on Birth Weight and Length of Gestation: Randomised Controlled Trial.” BMJ.

[58] Del Castillo, N., Jiménez-Moleón, J. J., Olmedo-Requena, R., Martínez-Ruiz, V., Bueno-Cavanillas, A., and Mozas, J. 2015. "Perinatal Outcomes of Prematurity and Birth Weight according to Maternal Caffeine Consumption.” Nutr Hosp 32: 2658-64.

[59] Lechat, M. F., Borlee, I., Bouckaert, A., and Misson, C. 1980. "Caffeine Study.” Science 207: 1296-7.

[60] Van’t, H. W. 1982. “Caffeine in Pregnancy.” Lancet 1: 10-20.

[61] Martin, T., and Bracken, M. 1987. "The Association between Low Birth Weight and Caffeine Consumption during Pregnancy.” Am J Epidemiol 126: 813-21.

[62] Del Castillo, N., Jiménez-Moleón, J. J., Olmedo-Requena, R., Martínez-Ruiz, V., et al. 2015. "Perinatal Outcomes of Prematurity and Birth Weight according to Maternal Caffeine Consumption.” Nutr Hosp 32: 2658-64.

[63] Stein, Z., and Susser, M. 1991. "Miscarriage, Caffeine, and the Epiphenomena of Pregnancy: The Causal Model.” Epidemiology 2: 163-7.

[64] Browne, M. L., Bell, E. M., Druschel, C. M., Gensburg, L. J., Mitchell, A. A., Lin, A. E., et al. 2007. "Maternal Caffeine Consumption and Risk of Cardiovascular Malformations: Birth Defects Research.” Clinical and Molecular Teratology 79 (7): 533-43.

[65] Gaskins, A. J., Rich-Edwards, J. W., and Williams, P. L. 2016. "Pre-Pregnancy Caffeine and Caffeinated Beverage Intake and Risk of Spontaneous Abortion.” Eur J Nutr.

[66] Weng, X., Odouli. R., and Li, D. K. 2008. "Maternal Caffeine Consumption during Pregnancy and the Risk of Miscarriage: A Prospective Cohort Study.” Am J Obstet Gynecol 198: 279 e1-e8.

[67] Poulsen, M. S., Rytting, E., Mose, T., and Knudsen, L. E. 2009. "Modeling Placental Transport: Correlation of in Vitro Bewo Cell Permeability and ex Vivo Human Placental Perfusion.” Toxicology in Vitro, 1380-86.

[68] Grant, I., Cartwright, J. E., Lumicisi, B., Wallace, A. E., and Whitley, G. S. 2012. "Caffeine Inhibits EGF-stimulated Trophoblast Cell Motility through the Inhibition of mTORC2 and Akt.” Endocrinology 153 (9): 4502-10.

[69] Partosch, F., Mielkeb, H., Stahlmanna, R., and Gundert-Remy, U. 2015. “Caffeine Intake in Pregnancy: Relationship between Internal Intake and Effect on Birth 
Weight.” Food Chem Toxicology 86: 291-7.

[70] Jahanfar, S., and Jaafar, S. H. 2009. "Effects of Restricted Caffeine Intake by Mother on Fetal, Neonatal and Pregnancy Outcome." Cochrane Database of Systematic Reviews 2.

[71] Jahanfar, S., and Jaafar, S. H. 2013. "Effects of Restricted Caffeine Intake by Mother on Fetal, Neonatal and Pregnancy Outcome." Cochrane Database of Systematic Reviews 2.
[72] Li, J., Zhao, H., Song, J. M., Zhang, J., Tang, Y. L., and Xin, C. M. 2015. "A Meta-Analysis of Risk of Pregnancy Loss and Caffeine and Coffee Consumption during Pregnancy." Int J Gynaecol Obstet. 130 (2): 116-22.

[73] Rhee, J., Kim, R., Kim, Y., Tam, M., Lai, Y., Keum, N., and Oldenburg, C. E. 2015. "Maternal Caffeine Consumption during Pregnancy and Risk of Low Birth Weight: A Dose-response Meta-analysis of Observational Studies." PLoS One 10 (7): 1-18. 